\title{
A Study and Analysis of Sanai's Illustration Techniques With a Mountain in Divan and Hadigheh al-Haqiqa
}

\section{Un estudio y análisis de las técnicas de ilustración de Sanai con una montaña en Divan y Hadigheh al-Haqiqa}

\author{
Zahra Ghazi Karbasi \\ PhD Student in Persian Language and Literature, Islamic Azad University, Neishabur Branch, \\ Iran \\ Batool Fakhr al-Islam \\ Member of the Department of Persian Language and Literature, Islamic Azad University, \\ Neishabur Branch, Iran

\section{Akbar Shabani} \\ Member of the Department of Persian Language and Literature, Islamic Azad University, \\ Neishabur Branch, Iran.

\section{Mehdi Norouz} \\ Member of the Department of Persian Language and Literature, Islamic Azad University, \\ Neishabur Branch, Iran.
}

Received 01-27-20 Revised 03-03-20 Accepted 05-17-20 On line 07-30-20

*Correspondence

Email: bt_fam12688@yahoo.com
Cite as:

Ghazi Karbasi, Z., Fakhr al-Islam, B., Shabani, A., Norouz, M. (2020). A Study and Analysis of Sanai's Illustration Techniques With a Mountain in Divan and Hadigheh al-Haqiqa. Propósitos y Representaciones, 8(3), e623. doi: http://dx.doi.org/10.20511/pyr2020.v8n3.623 


\section{Summary}

Sanai is considered one of the prominent mystic poets in the field of Persian literature. Relying on various concepts and techniques, he has described his ideas and by simplifying the ambiguous categories, he has increased the power of understanding of his audience. "Mountain" is one of the natural elements that has been repeated many times in Divan and Hadiqah al-Haqiqah. Using literary arrays and various forms of imagination, the poet has created new images that are somehow related to the "mountain". In the present article, based on descriptive method and content analysis technique, Sanai illustration techniques have been explored. The most important findings of the research show that the poet, using literary tools and symbolic capacities of the mountain, has succeeded in representing and explaining the moral and educational, mystical and epistemological concepts, romance and in some cases, descriptive application. And has been praised. Among imaginary forms, simile has the highest frequency and exaggeration has been the most frequent literary array. Using the aesthetic capacities of "Mountain", Sanai, in addition to creating pristine literary images, has made his epistemological ideas attractive and objective.

Keywords: Sanai; Divan; Hadiqah al-Haqiqah; Mountain; Ilustration.

\section{Resumen}

Sanai es considerado uno de los poetas místicos prominentes en el campo de la literatura persa. Basándose en varios conceptos y técnicas, ha descrito sus ideas y al simplificar las categorías ambiguas, ha aumentado el poder de comprensión de su audiencia. "Montaña" es uno de los elementos naturales que se ha repetido muchas veces en Divan y Hadiqah al-Haqiqah. Utilizando matrices literarias y diversas formas de imaginación, el poeta ha creado nuevas imágenes que de alguna manera están relacionadas con la "montaña". En el presente artículo, basado en el método descriptivo y la técnica de análisis de contenido, se han explorado las técnicas de ilustración de Sanai. Los hallazgos más importantes de la investigación muestran que el poeta, utilizando herramientas literarias y capacidades simbólicas de la montaña, ha logrado representar y explicar los conceptos morales y educativos, místicos y epistemológicos, el romance y, en algunos casos, la aplicación descriptiva. Y ha sido alabado. Entre las formas imaginarias, el símil tiene la frecuencia más alta y la exageración ha sido la matriz literaria más frecuente. Utilizando las capacidades estéticas de "Montaña", Sanai, además de crear imágenes literarias prístinas, ha hecho que sus ideas epistemológicas sean atractivas y objetivas.

Palabras clave: Sanai Diván; Hadiqah al-Haqiqah; Montaña; Ilustración.

\section{Introduction}

Mountains are of special importance in the general culture of mankind, including ancient Iran. Many important events have taken place in the mountains and various characters have undergone profound epistemological changes as they go to the mountains. The mountains have somehow been in contact with the afterlife, and amazing events have been seen in these places that have been instrumental in bringing about great changes among humans. In the religious and nonreligious narrations that have been given to us from the past, man's connection with God in the mountains is emphasized. That is why in many cultures, mountains are considered the place of gods and saints and the place of worship and worship of epistemologists. In the legend of Gilgamesh, "the Babylonian gods were on the holy mountain, and Sidori Sabito was called the wise woman of the mountain of heaven. "As the Greek gods were above Olympus." (Bastani Parizi, 1344: 389) In Mazdisna's religion, the house of Soroush, the guardian of the pure world and good creation, is located on top of the mountains. (Hills, 1377, p. 119)

In the Holy Quran, the mountain is of special importance and the intellectual frameworks mentioned in previous sources about the mountain are repeated in this text. The Qur'an mentions 
several benefits for the mountains, some of which are tied to basic human needs. Such as the use of water resources (Raad: 3; Nahl: 15), a place of rest and relaxation (Naba: 8-7) and human shelter (Nahl: 81). Some other benefits of the mountain are related to epistemological issues, the most important manifestation of which can be seen in the story of Moses (pbuh). God manifested the word of God in Sinai and explained His commands to him and recounted the policy of prophecy. Also, the mountain in the Qur'an is a comprehensible example to show the greatness of the Almighty. (Fatir: 27) Therefore, the element of the mountain in Islamic texts has a dual function: on the one hand, it provides a part of human biological needs and on the other hand, it is considered a place for the spiritual ascent of knowledgeable human beings.

Statement of the problema

Persian mystical literature has been formed under the influence of two main sources and has grown and flourished. First, pre-Islamic epistemological sources (Iranian and Greek works and ideas) and second, Islamic sources, with the Qur'an at the top. In other words, the foundation of the theoretical and practical foundations of Islamic mysticism has been formed based on these two sources. Sanai of Ghazni is considered one of the most important Persian-speaking poets, whose works are noteworthy for their special initiatives in the field of mystical issues. By intervening his mystical concerns in the form of Masnavi, ghazal and ode, he created a dramatic change in Persian poetry and became an example for other prominent figures such as Attar and Rumi. In addition, he is considered one of the leaders in Persian literature in presenting pristine literary images. Sanai's poetic atmospheres in Divan and Hadiqah al-Haqiqa can be studied both aesthetically and epistemologically. He has reflected part of his intellectual structure through the use of illustration techniques. Therefore, re-reading and paying attention to it becomes important and valid. One of the important concepts in the mentioned works, on which Sanai has succeeded in creating images and pristine literary spaces and explaining moral, mystical, descriptive, romantic, etc., is the mountain element. As a result, addressing the mountain element and the concepts around it is effective in understanding the intellectual structure of the Sanai of Ghazni. With regard to this issue, the main issue of the present article is the study and analysis of Sanai's illustration techniques with the mountain element in Divan and Hadiqah al-Haqiqah in order to answer the questions of what concepts the poet uses the mountain's visual capacities. Has it been designed and described? And which literary tool has he used the most to achieve this goal?

\section{Research background}

So far, no research has dealt with the concept of the mountain and its belongings in Sanai poems. Therefore, the present article can be considered innovative and its achievements new. However, in several articles, research has been done on Sanai's poetic illustrations. In his article, Nabiloo (2008) examines Sanai's linguistic and literary views. From the author's point of view, Hakim Ghazna has pointed to the role of meaning and words in language, the relationship between language and reason and thought, and the effect of language. Ittehadi (2010) has compared the external and lateral music of the sonnets of Sanai and Attar and has come to the conclusion that Sanai's poem is richer than the poems of Sheikh Neyshabouri. And Fallah Lalehzari (2012), in a research, have studied the external music of Ghaznavid Sanai lyric poems and have come to the conclusion that the poet has acted artistically in using this type of music. However, there is a very small percentage of weight objections among his sonnets, which is due to the preference of meaning over the form and appearance of poetry. Khorasani, Akhlaqi and Bahrami (2013), by phonetic analysis of Sanai's sonnets based on the school of formalism, have come to the conclusion that Sanai, according to his own school of thought, pays attention to the beautification of words, balance, sound and its induction. He has used all kinds of prostrations, puns and repetitions.

In the field of mystical literature, research has been done on the function of the mountain in these texts. Behnamofar and Zamani-Pour (2012), in an article, have studied the mountain and its symbolic meanings in expressing Rumi's mystical and romantic emotions in Masnavi. From the authors' point of view, the reflection of this natural element in Rumi's poetry shows that his 
great soul belongs to the manifestations of generosity, greatness and stability. In addition to its rigidity, the mountain inspires a great moral lesson, namely, unanimity while secrecy and refuge. Shabanzadeh and Alipour (2016) have studied the evolution of the functions of the meaning of Qaf Mountain. From the authors' point of view, many of the mythological features of Mount Qaf have been extended to mystical sources in the same original form. Also, the semantic aspect of Qaf and its functions in the early mystical texts is inclined towards the narratives of myths, and as we get to the following periods, the related concepts become more abstract, that is, Qaf from the form of myth. He goes out and finds a mystical body.

\section{Illustration techniques with the mountain}

\section{Illustration with simile.}

Simile is one of the imaginative literary elements that pushes the boundaries of the poet's imagination to infinity. The simile of the most widely used imaginary forms in the field of Persian literature has been its mystical type. Because in mysticism we encounter epistemological concepts that are often abstract and intangible, simile allows those concepts to be visualized and objectified, and the audience from the cultural group is able to communicate the issues of the project.

In Sanai's poetry, similes have had the highest frequency. From this point of view, the continuation of the literary and rhetorical tradition of Persian literature can be seen in his poem. Relying on the element of the mountain, he has made several illustrations in his poetry. For example, in the following poem, he talks about love and romance and states that although the tulips growing in the middle of the mountain are very pleasant and beautiful and remain the nymphs of heaven, but with the arrival of the government Love, these beauties fade. By creating a semantic confrontation between the "tulip growing in the mountains" and the "state of love", Sanai has explained the epistemological concept that apparent love becomes degraded and insignificant with the emergence of true love. In the following verse, the mountain is a symbol and a manifestation of a place that has embodied aesthetics.

Although in the middle of Laleh Mountain

Because the government fell in love Because it is seen in the middle of the nymphs These all came from the middle

(Sanai, 1388: 28)

In Sanaa's view, love is like the sea of the environment, and the sea water is like a fire that burns the lover. Therefore, the diver of the sea of unity faces indescribable difficulties, one of which is the waves that remain in the mountains of darkness. This analogy is very effective in the semantics of the audience; Because it is known that stepping on the path of love and affection will be accompanied by many ups and downs that will be beneficial in his growth and excellence. The mountain in the following verse indicates the greatness and greatness of the problems that Sanai has succeeded in explaining this concept by relying on the element of simile.

The love of the surrounding sea and seawater is fire The waves come as if they were mountains of darkness

(Same: 30)

Sanai is a mystic poet and has a romantic and intoxicating approach in this regard. In the following poem, he has expressed this view by relying on visual tricks. He considers the love of a lover (real / virtual) expensive and exhausting and beyond his power, and likens it to a mountain to objectify his feelings. His body is weak and emaciated and stays in the hair, and in contrast, the sorrow caused by the love of the beloved, which weighs like a heavy wedge. Elsewhere, he advises those who wish to step into the valley of love that they must endure hardships to better understand the subject. What has helped Sanai strengthen this view is the use of simile tools. He 
says that a loving person whose grass becomes like a mountain and a desert will hope for spiritual excellence and growth. The mountains and the desert in the following verse are a manifestation of the difficulties of life.

The mountain is the sorrow of your love, the hair of my body You can never pull a mountain into a hair

(Ibid: 309)

You are right in watching the path of love Until the ninth, there is no mountain grass and desert

(Same: 417)

One of the theological issues reflected in the Sanai Divan is his divine wrath and obedience. The poet believes that with the implementation of divine wrath, expensive mountains will bend like a meme ring. This beautiful simile and image expresses the infinite power and will of the Almighty, against which even the greatest and most difficult phenomena can not stand.

He has become angry with Kuh Garan Cho, the ring of Meem He was served behind the firmament of the signifier ring

(Ibid: 555)

In myths and literature from different cultures, positive and pleasant concepts are attributed to the mountain, but Ghazni Sanai with obvious semantic de-familiarization, with a different and new look, to some of the negative characteristics of the mountain (From his point of view) has pointed out. For example, he considers the mountain as a careless human being It is devoid of endeavor and activity, and makes no effort to grow and prosper, and spends its life in a slumbering sleep. The poet intends to show an objective picture of people who have intellectual and behavioral stagnation, and he has achieved this moral point by comparing the abovementioned people to the "clinging mountain".

The sun has risen now, like a mountain In the ray of light I fell helplessly

(Same: 512)

Sanai has had a praiseworthy and descriptive approach in some of his poems, especially odes. Shafiee Kadkani considers this part of Sanai's poems to be the "dark pole of his existence". (Shafiee Kadkani, 1390: 25) Perhaps Sanai's illustrations in the following verse better show his praiseworthy language. He exaggerated in praising "Colonel Amid Mohammad Khatib Heravi" and likened this person to a mountain in greatness and prominence and added that if the shadow of his plan falls on the ground, the sunlight will not reach the ground. The poet has portrayed the environment of Hazm Khatib Heravi in this way.

A shadow falls from the mountain on the ground Do not turn the sun until the resurrection

(Sanai, 1388: 519)

The description and praise can also be seen in the following verse. His praiseworthy poet praises "Abu al-Ma'ali Yusuf ibn Ahmad" and highlights his attribute of learning. From Sanai's point of view, Abu al-Ma'ali is the general rule to which knowledge, as a part of this whole, tends. He goes on to point out that the credibility of his government is like a flood coming from the mountains and having a lot of power and roar. A sensible analogy to the tangible allows Sanai to best describe one of his praiseworthy abstract attributes to the audience. According to this analogy, mountains, as the place where floods occur, have unbridled and destructive power. 
The desire for knowledge is towards you because the desire for components is towards the whole water of the government

(Ibid: 537)

The heart connection with God on the top of the mountain is stronger and more spiritual because of its glory and majesty; (Rashdmohsal, Behnamfar and Zamanipour, 1391: 130) Because "the mountain is closer to the sky than all objects of nature. This feature is enough to sanctify the mountain. "On the one hand, the mountain is the symbol of spiritual upliftment, and on the other hand, it is the supreme scene of the manifestation of the heavenly sanctities and, as a result, the center of the gods." (Shavalieh and Bergaran, 2006: 126) Sanai in the court has repeatedly referred to the epistemological functions of the mountain. In his view, the mountain is the abode of the men of God, and those who seek knowledge spend part of their lives in the mountains and gain true knowledge. On this basis, the poet, who is in love with the mystic, addresses his like-minded people and says that it is very difficult to enter the path of love and knowledge to God, and the men of the desert move forward like mountains, steadfast and resilient. Otherwise, for fear of the calamities that are seen in this way, they hide under a mound of quicksand and, ultimately, stay away from understanding and receiving true knowledge. The confrontation between the mountain and the back of the sand has added to the objectivity of Sanai's content.

Or we will appear in the desert of men like a mountain Or hide under the back of quicksand

(Sanai, 1388: 572)

The first verse is composed in praise of "Khajeh Hakim Hassan Asad Ghaznavi". The poet likens his praiseworthy stillness to mountains and canyons. What adds to the beauty of this analogy is the poet's multi-layered look. He describes the eunuch as a stable mountain and at the same time calm, and goes on to say that in the shadow of this stillness he has reached a level of knowledge and cognition that has institutionalized the essence of morality. Is. So, we come to the part where we talk about the middle ground. In the first layer, Mamdouh is like a mountain (pseudo-face: stillness) and in the next layer, it is like a mountain (pseudo-face: being valuable). The second verse, written in praise of one of the elders, has another metaphor in its heart. Sanai considers his praiseworthy patience as a mountain; Because the mountain, with all its strength and power, stands in its place and is calm. Mamdouh, with all its grandeur, behaves calmly and patiently. These similes have a tremendous effect on increasing the audience's level of understanding because they are simple and easy to understand and have special illustration capabilities.

Hafez is like a pure memory like a resident substance like a mountain and a cane, bright like an

(Ibid: 762)

Not to the grave of my dream in the mountains Not by nature, you are a big leopard

(Ibid: 567)

In the following verse, Sanai has a positive teaching approach. He advises his audience to be patient and patient. According to the poet, when science and dream are combined, there will be good positive effects on a person's personality, one of which is to endure the hardships of the times.

Do you know how to dream? Do not be annoyed by the deputies

(Sanai, 1383: 17) 


\section{Illustration with exaggeration and exaggeration.}

An exaggeration in the word "much effort and extravagance at work" and in the term of modern science, is a transgression of reality, so that the poet with the author describes someone or something in the word and meaning in such a way that the attributes attributed to it exceed the normal limit. Or appear beyond normal. In other words, it is a descriptive exaggeration in which exaggeration is accompanied by emphasis on exaggeration. (Taftazani, 1409 AH: 434; Kashfi Sabzevari, 1369: 113) Abu Hilal Askari also says about this array: "Do not neglect the closest level." (Al-Askari, 1319 AH: 287) Therefore, exaggeration means excessive in praising or denouncing the physical and moral characteristics of a person.

In Sanai poetry, votesExaggeration of the mountain has been repeated many times. In the following verses, out of spiritual despair, the poet addresses the Muslims and says that he does not find a way to cure the pain of his lover's heart and knows the solution in lovemaking. Then, relying on an array of exaggerations, he presents an exaggerated state of his love to his friend, saying that from the extent of my love, the waters of the seas evaporate and the mountains disintegrate and fall on us. It turns. The intensity of love fades the lover of the mountains in all its grandeur and leaves no trace of them.

O Muslims, I do not know how to do it The water of the seas burns and the mountains burn Or unless I miss his love ... I saw it because I was going to add water

(Sanai, 1388: 264)

By mentioning Mount Qaf, Sanai has expressed part of his intention by relying on exaggeration. In ancient texts, Mount Qaf is mentioned as the origin of unknown worldly and otherworldly phenomena. "The roots of all the mountains are from the veins of Mount Qaf. Some have said that there is a distance between the neck of the neck and the sky as much as a man ... Beyond the neck is a part of the Hereafter. "The sun rises from it and sets in it." (Yaqut Hamavi, 1977, vol. 4: 298) With this approach in mind, Sanai breaks the greatness of Qaf to emphasize the importance of the subject he has in mind, namely the greatness and arrogance of the Almighty. He believes that Qaf, in all its grandeur, collapses when it sees the shadow of God's arrogant cuff, and its foundation is destroyed. Therefore, all the powers and greatness of the world and beyond are of no value to the divine power.

The neck itself collapses From the shadow of your cobra

(Sanai, 1388: 358)

One of the important personalities that has been dealt with and mentioned in the Sana'i court is the Prophet of Islam. In the following verse, the poet praises his positive moral qualities and states that no one is like Muhammad (PBUH) in knowledge and patience. To better explain this view, Sanai mentions Kof Qaf that Ramzi is one of the epistemological issues and because of its height, it is considered as a symbol of the peak of true knowledge and cognition. According to this mythical statement, the dignity and rank of the Prophet of Islam in the field of epistemological issues is far beyond this mysterious mountain.

Where do they have knowledge and patience of his existence? Scholars of the worlds and the mountain of Qaf and Abruim

(Ibid: 537)

Exaggeration is one of the most important literary tools for poetic descriptions and praises. In the first verse, Sanai describes Abu Bakr ibn Muhammad with the use of an array of exaggerations and considers his greatness and social status as superior and beyond the mountains 
and emphasizes that no one knows who has experienced such rank and glory. . In the second stanza, Sanai praises his other praiser, Bahram Shah, by relying on the element of exaggeration and linking this array to the mountain. He says that when Bahram-Shah appears on the battlefield and attacks his enemies, the firmness of his steps is as if he has stepped on Qaf.

I have not seen this mountain because you are dignified Wayne Charzadeh Nazadeh Choo Spatial Orientation

(Same: 827)

Especially when he was in a fight His foot was on his nose (Sanai, 1383: 324)

\section{Illustration with hints.}

An allusion is a spiritual array "in which the poet or writer, in his speech, refers to a story, verse, hadith, event, specific biography, proverb, and famous poem." (Vahidian Kamyar, 1383: 67) In Sanai's poetry, the hints in which the mountain is mentioned have a religious basis. In the following verse, a subtle allusion to Mount Toor and the Nile River can be seen. When Moses (pbuh) moved from Egypt to his homeland, he noticed sparks of fire in the Sinai region and his attention was drawn to it. He went to the mountains to find out about the incident, and finally, he talked to the Almighty, and as a result, his prophetic mission was completed. Using this story, Sanai has described the knowledge and moral richness of his friend. In praise of his beloved friend, he states that the mountain of fire (fire of passion and knowledge) is always present in him and a sea of goodness flows in it.

By the sea, the slave is your laugh The mountain of fire is always with you

Thank you, what about Soraya?

Do not say mountain of fire, nor sea

(Sanai, 1388: 268)

The mountain is of special importance in religious menus; Because "the prophets revealed their religion to the people from the mountains, and its objective connection is established in the mountains that have found an exemplary status." (Mokhtari, 1379: 101) including the CIA, which was the place of conversation between Moses (AS) and Yahweh (the God of the Kalimians). Sanai's allusive look at the mountain is reflected in the mirror of the lyric poems. He believes that science and knowledge will be effective when it adds to the epistemological aspects of human personality, not just the title of the universe. In other words, Sanai emphasizes on increasing the knowledge of the original science and in confirming his words, he mentions a religious implication which has been narrated based on the element of the mountain. He believes that every human being will not undergo fundamental changes by going to the mountains and should use all his existential capacities to reach the level of Moses (AS) and become a prominent person.

Science should take your place and issue Otherwise, no one will be Musa Imran

(Sanai, 1388: 314)

In human culture, crossing a mountain symbolizes passing from one stage to another. Hence, ascending and ascending a mountain not only symbolizes the attainment of holiness, but also the passage of the soul through the world. (Rashed Mohassel, Behnamfar and Zamani-Pour, 1391: 126) According to this statement, what happens in the mountains is the connection of man in the material world with the transcendental world. Sanai with care bThis cultural and intellectual tradition believes that whenever a person feels the luminous passions of the mountain in his existence, he should go towards it in order to turn the epistemological sparks of his existence into the fire of passion and true love. Slowly To express his point of view, the poet cites Moses (AS) 
as an example and introduces him as a true seeker and reminds him of his cognitive experience in Sinai.

Where the light shines from. Where do you find iron?

Go on experience like Musa Ibn Imran

(Sanai, 1388: 437)

Learn from Moses if you want to

Cross the mountain and shit on the bottom of the sea

(Sanai, 1388: 493)

\section{Metaphorical illustration.}

Mountain-related metaphors are not very common in Sanai poems. In three cases, using metaphor, Sanai has succeeded in creating prominent images with the mountain element and has explained his intended concepts. In the following verse, he creates a semantic confrontation between Jesus and the donkey. In Persian literature, Jesus is a metaphor for the soul and spiritual matters in general, and the donkey is a metaphor for the body and material matters. "As big and majestic as the mountain is, the straw is very small and light. "As a way to better show the size of a mountain, it can be compared to a straw." (Namvar Motlagh, 1379: 80) The poet believes that perfect human beings live in a world full of contradictions and confrontations, on the one hand, epistemological issues and on the other hand, the affairs of this world. They are standing in line. The virtue of self-fulfilling prophecies is to get off the donkey of materialism by choosing the right one and promoting spirituality, and to walk on the path of personal excellence.

Jesus and the donkey are both present in our house Go up the mountain to Jesus and put the straw in front of the donkey

(Sanai, 1388: 473)

Sanai talks about his friend Negarin and his side, that he has a boat on his head and when the moon sees him, they kiss his feet and a fragrant wind swirls around his face. In the third stanza, Sanai's metaphorical gaze culminates and is mixed with exaggeration to state that the mountain opens its head when it sees this friend. The mountain is thought of as a human being wearing a hat. The poet has given this natural element a human personality and emphasized its greatness and awesomeness. In his view, the mountain, with all its greatness, sees this friend and shakes its head.

I'm intoxicated

The gloomy moon is kissed by two lips The mountain is open from that head and from the end of grace

With a one-sided boat shirt on his head ... The perfumed wind on the two lights of the sham ring The moon is on a wheel, closed on its chest and on

(Ibid: 482)

Sanai has introduced the mountain as Ganjour Sepehr; Because in its heart, there are huge amounts of Crimean stones, in other words, it has placed many treasures in its heart. For this reason, the poet brings the treasure (guardian of the treasure) in the following verse, which is a metaphor of the mountain. Therefore, Sanai has pointed to the natural properties of this element.

The precious goat of Ganjoor Sepehr came to the mountain The lightness of the toy came from the wind

(Ibid: 549) 


\section{Illustration with irony.}

In rhetorical books, irony is one of the imaginary forms and besides similes, metaphors and metaphors, it gives depth and other dimensions to literary texts such as poetry and provides the possibility of interpreting poetry. "The irony of leaving is to specify something and to mention its necessity in order to understand what has been abandoned by that necessity." (Sakaki, 1937: 189) In Sanai's poetry, irony is effective in representing a part of his intellectual structure. He uses repetitive and innovative allusions to describe his ideas. Most of these ironies are simple and easy to understand, and the audience does not need much research to find out the poet's hidden purpose. This makes it easier for the audience to communicate with the created text.

Using this imaginary form, Sanai has recounted various concepts about the mountain. In order to show the relationship between God and the servant - which in his view is based on love and affection - he states in the language of the Almighty that man has been drunk with the syrup of enthusiasm and longing rather than drunken and unconscious manifestation. And in the next step, remove the earthly veils from his eyes and show him the truth of his nature. Sanai believes that God accepts the good behavior of human beings, even if it is as small as a millet and a particle, and in return reduces their sins to the size of a mountain. The poet has shared his meaning well with his audience with the ironic phrase "mountain of death". The mountain has been chosen because "it is one of the most important symbols to show the awe and firmness of the soil" (Namvar Motlagh, 1379: 80) and by relying on the volume and size of this natural element, the degree of generosity of the Almighty is better materialized.

I long for syrup to make you drunk Little by little, I will accept your kindness from you I will unveil and then I will worry about you Mountain of mountains, I will pass from you to sin

(Sanai, 1388: 567)

The mountain is a metaphor for doing something amazing. In the following verse, Sanai addresses the heedless human beings who say that the nine heavens are rotating by divine providence and that the times are governed in an unparalleled order. In other words, these divine media deliberately keep the whole universe in their correct orbit. However, the careless servant, instead of clinging to these strings, throws himself into the well of error and does a wonderful and unreasonable thing by relying on worldly and material means.

Turn the wheels with the divine media and you Go to the straw in a well and a mountain

(Same: 607)

\section{Conclusion}

Sanai uses the visual capacities of the mountain to represent and explain the concepts of moral and educational, mystical, romantic and descriptive. And praise has done better and given objectivity to a significant portion of its mental holdings. Among the literary tools that Sanai has used the most for illustration are frequency, simile, exaggeration, and allusion, respectively. The images created by Sanai have often been innovative. The quality of his art in this field has been so prominent and prominent that poets after him have used the illustrations used in Divan and Hadiqah al-Haqiqa many times. In Sanai's poems, it is not enough to mention only the positive and well-known features of the mountain, and the poet, by relying on unfamiliarity, likens this natural element to a careless human being. The similes that the poet illustrates using his abilities have a simple and familiar structure. The exaggerations used in Divan and Hadiqah al-Haqiqah often have a praiseworthy and descriptive function, and the poet has used this array to satisfy his praisers. The metaphors seen in Sanai's poems and related to the mountain have a limited surface and are very easy to find. Although mystical language is interpretable and metaphorical, it has not 
been given much attention in Sanai's poems about the mountain. The allusions, which are somehow connected with the mountain, come from the religious (Islamic) culture of Sanai and are reminiscent of the stories of the prophets. Also, mountain-related allusions are easy to find and the audience will have little difficulty understanding them.

\section{References}

Ittihadi, Hossein, (2010), "A Comparative Study of External and Side Music of Sanai and Attar Ghazals", Persian Literature Quarterly of Islamic Azad University of Mashhad, No. 28.

Al-Askari, Hassan bin Abdullah, (1319 AH), Industry, Books and Poetry, researcher Ali Muhammad Bahawi, Beirut: Lebanon.

Amir Mashhadi, Mohammad and Fallah Lalehzari, Maliheh, (2012), "External music of Ghaznavid Sanai ghazals", Persian Language and Literature Quarterly of Islamic Azad University of Sanandaj, 4(13).

Bastani Parizi, Mohammad Ibrahim, (1344), Khatoon Haftaghaleh, Tehran: Soroush.

Behnamofar, Mohammad and Zamani-Pour, Maryam, (2012), "Mountain and its symbolic meanings in expressing the mystical and romantic emotions of Rumi in Masnavi", Research Journal of Lyrical Literature, Sistan and Baluchestan University, 10(19).

Hinels, John, (1998), Understanding Iranian Mythology, translated by Jaleh Amoozgar and Ahmad Tafazli, Tehran: Cheshmeh.

Khorasani, Mahboubeh and Akhlaghi, Akbar and Bahrami, Samaneh, (2015), "Phonetic analysis of Sanai lyric poems", Research in Literary Criticism and Stylistics of Shahrekord Islamic Azad University, No. 21.

Knight, Jean and Gerberan, Allen, (2006), Culture of Symbols, translation and research by Soodabeh Fazaili, Tehran: Jeyhun.

Kashefi Sabzevari, Hossein Vaez, (1369), The Origin of Thoughts in the Poetry Industry, Edited and Presented by Mir Jalaluddin Kazazi, Tehran: Center

Mokhtari, Mohammad, (1379), The Myth of Zal, Tehran: Toos.

Namvar Motlagh, Bahman, (1379), "Symbolic confrontation of wind and mountain with Rumi and St. Exupery", Foreign Languages Research, No. 8.

Nabiloo, Alireza, (2009), "A Study of Sanai Linguistic and Literary Perspectives", Quarterly Journal of Literary Research, 6(22).

Rashed Mohassel, Mohammad Reza and Behnamofar, Mohammad and Zamani-Pour, Maryam, (2012), "Manifestation of the mountain in ancient Iran and a look at its effects in Persian literature", Journal of Iranian Studies, Shahid Bahonar University of Kerman, 11(21).

Sakaki, Abu Ya'qub Yusuf ibn Muhammad ibn Ali, (1937), Muftah al-Uloom, introduction and research by Dr. Abdul Hamid Hindawi, Beirut: Dar al-Kitab al-Ulmiya.

Sanai, Majdood Ibn Adam, (2004), Hadiqah al-Haqiqah and Shari'ah al-Tariqah, edited by Dr. Mohammad Taghi Modarres Razavi, sixth edition, Tehran: University of Tehran.

Shabanzadeh, Maryam and Alipour, Ismail, (2016), "From Myth to Mysticism: A Study of the Concept of Semantic Functions of Qaf", Journal of Mystical Literary Research (Gohar Goya), 10(1).

,(2009),

Divan, Introduction and Index by Mohammad Taghi Modarres Razavi, seventh edition, Tehran: Sanaei.

Shafiee Kadkani, Mohammad Reza, (2011), The Whips of Salom, Tehran: Ad.

Taftazani, (1409 AH), Al-Matul, Bahamsheh Al-Sayyid Mir Sharif, Qom: Al-Dawari School.

The Holy Quran.

Vahidian Kamyar, T. (1383), Badie, first edition, Tehran: Samat.

Yaghoot Hamavi, (1977), Dictionary of Countries, Beirut: Dar Sader 